Symptomatic Subjects 
ALEMBICS: PENN STUDIES IN LITERATURE AND SCIENCE

Mary Thomas Crane and Henry S. Turner, Series Editors 


\title{
Symptomatic Subjects
}

\author{
Bodies, Medicine, and Causation \\ in the Literature of Late Medieval England
}

\section{Julie Orlemanski}

\section{$\overline{\text { PENN }}$}

UNIVERSITY OF PENNSYLVANIA PRESS 
Copyright (C) 2019 University of Pennsylvania Press

All rights reserved. Except for brief quotations used for purposes of review or scholarly citation, none of this book may be reproduced in any form by any means without written permission from the publisher.

\author{
Published by \\ University of Pennsylvania Press \\ Philadelphia, Pennsylvania I9IO4-4II2 \\ www.upenn.edu/pennpress
}

Printed in the United States of America on acid-free paper

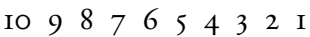

Library of Congress Cataloging-in-Publication Data

Names: Orlemanski, Julie, author.

Title: Symptomatic subjects : bodies, medicine, and causation in the literature of late medieval England / Julie Orlemanski.

Other titles: Alembics.

Description: Philadelphia : University of Pennsylvania Press, [2019] | Series: Alembics : Penn studies in literature and science | Includes bibliographical references and index.

Identifiers: LCCN 20I8045209| ISBN 97808I2250909 (hardcover : alk. paper) | ISBN 0812250907 (hardcover : alk. paper)

Subjects: LCSH: Literature and medicine-England-History-To I500. | Diseases-England-Causes and theories of causation-History-To I500. | English literature-Middle English, IIOO-I5Oo-History and criticism. | Human body in literature. | Causation in literature.

Classification: LCC R702 .O75 2019| DDC 610.942-dc23

LC record available at https://lccn.loc.gov/2018045209 
For my family 
This page intentionally left blank 